\title{
Kinesiotaping Effects on Shoulder Pain, Mobilization and Functional Capacity in Leisure Basketball Athlete
}

\author{
Vitriana Biben, Yudit Sandya, Tertianto Prabowo
}

Department of Physical Medicine and Rehabilitation, Faculty of Medicine Universitas Padjadjaran, Dr. Hasan Sadikin General Hospital, Bandung, Indonesia

\begin{abstract}
Introduction: Shoulder pain is a common issue among basketball players and it can decrease their range of motion (ROM) and overall upper limb functional ability. Kinesiotaping modulates pain mechanoreceptors on the skin and thus can reduce pain and improve shoulder ROM.

Methods: This study aims to evaluate the effects of KT application on the severity of pain, shoulder mobilization, and functional ability of the upper limb in leisure basketball players. Quantitative quasiexperimental method with intervention design in 32 basketball leisure athletes was used. Pain was assessed by using the $100 \mathrm{~mm}$ Numeric Rating Scale instrument, shoulder flexion and abduction were measured using a goniometer and the Shoulder Pain \& Disability Index (SPADI) instrument was used to assess upper limb functional ability.
\end{abstract}

Results: There was a significant decrease in shoulder pain ( $4.78 \pm 0.79$ to $2.90 \pm 1.42$ on day $5, \mathrm{p}=0.05)$, and an increase in flexion and abduction (on day $5, \mathrm{p}=0.05$ for flexion and $\mathrm{p}=0.05$ for abduction). There was also a significant increase $(\mathrm{p}=0.05)$ in upper limb functional ability after the intervention.

Conclusion: KT application shows benefits in decreasing shoulder pain and increasing shoulder mobilization and functional ability of upper limb during first $3^{\text {rd }}$ day until $5^{\text {th }}$ day application.

Keywords: functional abilities, kinesiotaping, mobilization, pain, shoulder joint 


\section{ABSTRAK}

Pendahuluan: Sendi bahu mempunyai peran yang besar pada kemampuan fungsional seseorang. Nyeri bahu merupakan hal yang umum ditemukan pada pemain basket karena pergerakan berulang. Nyeri berdampak pada berkurangnya rentang luas gerak sendi (LGS) dan kemampuan fungsional alat gerak atas secara keseluruhan. Kinesiotaping (KT), memodulasi mekanoresptor nyeri pada kulit, sehingga menurunkan nyeri dan memperbaiki rentang LGS bahu.

Metode: Penelitian ini berusaha mengetahui efek aplikasi KT pada nyeri, mobilisasi sendi (fleksi dan abduksi) dan kemampuan fungsional alat gerak atas pada atlet rekreasional basket. Metode quantitative quasi-experimental dengan rancangan intervensi dipergunakan pada 32 pebasket. Skala nyeri dinilai dengan instrumen $100 \mathrm{~mm}$ Numeric Rating Scale, mobilisasi bahu diukur dengan goniometer serta Shoulder Pain \& Disability Index untuk menilai kemampuan fungsional alat gerak atas.

Hasil: Terdapat penurunan bermakna tingkat nyeri (pada hari ke 5, $\mathrm{p}=0,05$ ), peningkatan fleksi (pada hari ke $5, p=0,05$ ) dan abduksi (pada hari ke 5, p =0,05). Kemampuan fungsional alat gerak atas mengalami peningkatan bermakna $(\mathrm{p}=0,05)$.

Kesimpulan: Aplikasi KT menurunkan nyeri, meningkatkan mobilisasi sendi serta kemampuan fungsional alat gerak atas untuk aplikasi pada hari ke 3 hingga hari ke 5 .

Kata Kunci: kemampuan fungsional, kinesiotaping, mobilisasi, nyeri, sendi bahu.

Correspondent Details:

\section{Vitriana Biben}

Email : vitriana02@gmail.com

Department of Physical and Rehabilitation

Medicine, Faculty of Medicine Universitas

Padjadjaran, Dr. Hasan Sadikin General

Hospital, Bandung, Indonesia

\section{INTRODUCTION}

Shoulder pain is a common musculoskeletal disorder, and it is reported as one of the five top ranks as musculoskeletal complaint and second most common pathology following lower back pain. ${ }^{1,2}$ Population surveys show shoulder pain affects $18-26 \%$ of adults at any point in time and can be seen as a persistent symptom that is associated with disability that may lead to difficulty in doing daily life, work, and leisure activities. ${ }^{1,3}$

Risk factors that affect the incidence of shoulder pain can be classified as non-occupational (such as gender, obesity, older age, coexisting medical disorder, and psychological factors) and occupational risk factors (activities that involve repetitive overhead action). ${ }^{3,4}$ Athletes who practice throwing above the head, like basketball, present a higher probability of developing shoulder injuries, it is because the motion of throwing involves this joint to be a part of the main gesture The overhead throwing motion generates tremendous demand on the glenohumeral joint at excessively high angular velocities..$^{5,6}$

Management of shoulder pain varies greatly based on the time and severity of the disease. The treatment goal is to relieve pain, reduce 
inflammation, prevent muscle atrophy, and restore the motion of joints without pain. Some modalities can be used as additional therapy, one of them is the use of taping. ${ }^{7,8}$ The underlying mechanisms of taping effects are still unclear. Clinical research in a systematic review showed the effectiveness of $\mathrm{KT}$ in reducing pain and improving joint motion, restoring joint kinematics, improving lymphatic circulation, and improving proprioception. ${ }^{7,9}$ Gate control theory, being the most described so far, justifies the hypoalgesic effect; and the effects were only found in short term ( 24 hours to 1 week). ${ }^{8}$

Kinesiotaping has now been widely used in various injuries involving the musculoskeletal structure as both means of treatment and prevention, but only a few studies show significant results with inadequate study methodology. ${ }^{9}$ Study on the effect of KT in shoulder pain, range of motion, and upper limb function is still limited. Recent studies indicate that KT may provide some short-term gains (effects produced by KT up to 24 hours after the application) with respect to pain and range of motion (ROM) of the shoulder, and so this study aims to investigate the effect of KT on the severity of pain, shoulder pain-free movement and functional activity in medium-term effects (effects produced by KT 24 hours to 1 week after KT application) in shoulder pain subjects. ${ }^{10}$

\section{METHODS}

A quantitative quasi-experimental method with consecutive sampling method was done to 32 participants at the C-Tra Arena Basketball Court, Dago Stamford International School Basketball Court, Basketball Cemara - Soekarno Hatta
School Basketball Court, and Antapani Basketball Court from February until September 2017.

Male subjects who complained of shoulder pain within an age range of 20-30 years old, have a history of shoulder pain accompanied by the decrease of motion in the shoulder joint, able to follow oral instructions, and signed approval to participate in the study were included. Subjects were excluded if they had a history of arthritis that causes recurrent inflammation or upper extremity surgery. Subjects will be dropped out if they are allergic to KT, have a recurrent injury in the same shoulder that KT is being applied to, and if KT application was loose or accidentally peel off during the study. Subject characteristics including age, gender, pain severity, shoulder flexion and abduction range of motion, and functional ability of the upper limb were taken through history taking and physical examination. Pain severity data were collected using a $100 \mathrm{~mm}$ (0-10 score) of Numeric Rating Scale (NRS), with the number 0 indicating no pain and the number 10 meaning the most intense pain that the subject felt. The shoulder joint range of motion (ROM) was taken using a goniometer. Subjects were asked to stand, flex and abduct their arms until the end range of motion. Data of the upper limb functional ability were collected using the score of Shoulder Pain \& Disability Index (PADI) questionnaire.

The tape that was used is Kinesiotaping, which was applied by a researcher that has been certified for KT application, with the "I strip" method on the shoulder of the subjects (Figure 1), with $0 \%$ tension of the tape. Data of NRS score, ROM of shoulder joint (flexion and abduction), and score of SPADI were taken on $1^{\text {st }}, 3^{\text {rd }}$, and $5^{\text {th }}$ day after KT application. 


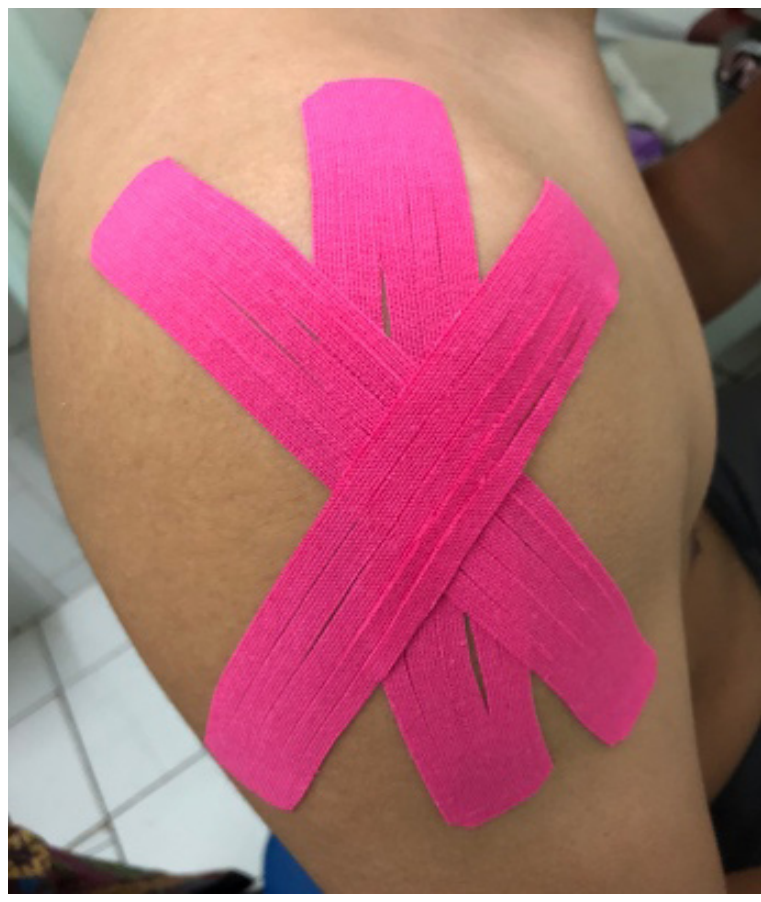

Figure 1. Kinesiotaping Application

Distribution of numerical data were calculated using Saphiro-Wilk test. Significance of pre and posttest intervention was determine using $\mathrm{t}$ test and Wilcoxon test, with $\mathrm{p} \leq 0.05$ is considered as statistically significant. The data processed using SPSS version 24.0 for Windows. This study was done after having permission from Health Research Ethics Committee Faculty of Medicine Universitas Padjadjaran Bandung with Registration Number 0317101100.

\section{RESULTS}

Thirty-two subjects were participating with not normally distributed data on all variables with no significant differences $(\mathrm{p} \leq 0.05)$ on the NRS, ROM and SPADI score before and after $1^{\text {st }}$ day of application (Table 1), but showed statistically significant decrease of pain, increase ROM of shoulder joint and upper limb functional after $3^{\text {rd }}$ and $5^{\text {th }}$ day of KT application (Tables 2 and 3).

Table 1. Comparison of Pain Severity, Shoulder Range of Motion and Upper Limb Functional Ability Before and After 1st day KT Application

\begin{tabular}{|c|c|c|c|}
\hline Variables & $\begin{array}{l}\text { Before Application } \\
\qquad \mathrm{N}=\mathbf{3 2}\end{array}$ & $\begin{array}{l}1^{\text {st }} \text { day } \\
N=32\end{array}$ & $p$ value \\
\hline Pain Scale (NRS)** & & & 0.157 \\
\hline Median & 5.00 & 5.00 & \\
\hline Range (min-max) & $3.00-6.00$ & $2.00-6.00$ & \\
\hline Flexion (Degree)** & & & 1.000 \\
\hline Median & 110.00 & 110.00 & \\
\hline Range (min-max) & $66.00-177.00$ & $66.00-177.00$ & \\
\hline Abduction (Degree)** & & & 1.000 \\
\hline Median & 121.50 & 121.50 & \\
\hline Range (min-max) & $64.00-178.00$ & $64.00-178.00$ & \\
\hline SPADI (Figure)** & & & 1.000 \\
\hline Median & 62.00 & 62.00 & \\
\hline Range (min-max) & $32.00-89.00$ & $32.00-89.00$ & \\
\hline
\end{tabular}


Table 2. Comparison of Pain Severity, Shoulder Range of Motion and Upper Limb Functional Ability Before and After $3^{\text {rd }}$ day KT Application

\begin{tabular}{lccc}
\hline \multicolumn{1}{c}{ Variables } & $\begin{array}{c}\text { Before Application } \\
\mathbf{N}=\mathbf{3 2}\end{array}$ & $\begin{array}{c}\mathbf{1}^{\text {st }} \mathbf{\text { day }} \\
\mathbf{N}=\mathbf{3 2}\end{array}$ & p value \\
\hline Pain Scale (NRS)** & & & $0.00^{*}$ \\
Median & 5.00 & 4.00 & \\
Range (min-max) & $3.00-6.00$ & $1.00-6.00$ & $0.00^{*}$ \\
Flexion (Degree)** & & & \\
Mean \pm STD & $120.00 \pm 30.56$ & $133.31 \pm 28.92$ & $0.00^{*}$ \\
Range (min-max) & $66.00-177.00$ & $57.00-180.00$ & \\
Abduction (Degree)** & & & \\
Median & 121.50 & 139.50 & $0.00^{*}$ \\
Range (min-max) & $64.00-178.00$ & $78.00-180.00$ & \\
SPADI (Figure)** & & & \\
Median & 62.00 & 50.00 & \\
Range (min-max) & $32.00-89.00$ & $9.00-88.00$ & \\
\hline$*: p \leq 0.05=$ statistically significant; $* *$ data not normally distributed; $* * *$ data normally distributed
\end{tabular}

Table 3. Comparison of Pain Severity, Shoulder Range of Motion and Upper Limb Functional Ability Before and After 5th day KT Application

\begin{tabular}{lccc}
\hline \multicolumn{1}{c}{ Variables } & $\begin{array}{c}\text { Before Application } \\
\mathbf{N}=\mathbf{3 2}\end{array}$ & $\begin{array}{c}\mathbf{5}^{\text {th }} \text { day } \\
\mathbf{N}=\mathbf{3 2}\end{array}$ & p value \\
\hline Pain Scale (NRS)** & & & $0.000^{*}$ \\
Median & 5.000 & 3.000 & \\
Range (min-max) & $3.00-6.00$ & $0.00-5.00$ & \\
Flexion (Degree)** & & & $0.000^{*}$ \\
Median & 110.00 & 152.00 & \\
Range (min-max) & $66.00-177.00$ & $60.00-180.00$ & $0.000^{*}$ \\
Abduction (Degree)** & & & \\
Median & 121.50 & 164.00 & \\
Range (min-max) & $64.00-178.00$ & $88.00-180.00$ & $0.000^{*}$ \\
SPADI (Figure)** & & & \\
Median & 62.00 & 36.00 & \\
Range (min-max) & $32.00-89.00$ & $0.00-86.00$ & \\
\hline
\end{tabular}

Note: The sign * indicates a value of $\mathrm{p} \leq 0.05$ which means significant or statistically significant. The $* *$ sign indicates that the data is not normally distributed. 


\section{DISCUSSION}

Shoulder injuries are common in athletes, the complexity of shoulder girdle function contributes to the variety of injury types, any of which may be associated with restriction of glenohumeral ROM. ${ }^{11}$

Management of shoulder pain is varied based on its etiology. Kinesiotaping is currently used in clinical practice in conjunction with other modalities and therapy. According to its creator, KT provides (1) correction of muscle function by strengthening weak muscles; (2) cutaneous stimulation, which facilitates movement limitation; (3) aid in the reduction of edema by directing exudates toward the lymphatic duct and the lymph nodes; (4) correction of joint positioning for easing muscle spasms; and (5) reduction of pain by neural pathways. ${ }^{12}$

This study found that the application of KT in shoulder pain significantly reduced pain severity by NRS score after the 3rd day of application (Table 3 and 4). The effect of KT in reducing shoulder pain in this study supports the result of the studies done by Thelen et al. and Kaya et al. that suggests that KT has an immediate effect on relieving shoulder pain. ${ }^{7,13}$ Some hypotheses were made to understand how KT provides pain relief. One hypothesis is that the cutaneous stretch stimulation provided by KT may interfere with the transmission of mechanical and painful stimuli.

KT may provide afferent impulses, facilitate pain inhibitory mechanisms (gate control theory) and pain reduction. Gate control theory is an act done by increasing "afferent feedback" through the mechanoreceptors on the skin that will send tactile signals through fast-conducting fibers $(A \beta)$, performing synapses with inhibitory interneurons when reaching the Ronald's Gelatinous Substance (posterior horn of the spinal cord), causing the closure of the gate and not allowing the passage of notion sensory stimulus ( $\mathrm{C}$ and $\mathrm{A} \delta$ fibers).$^{14}$ The tape also provides sensorimotor feedback that only allows movements that cause minimal mechanical irritation of the tissues; hence less pain occurs. In this regard, using three KT stripes in this study, the same protocol in the study done by Paolini et al., might lead to an increased involvement of cutaneous receptors. ${ }^{8,12}$

Application of KT on the skin was also hypothesized to relieve pressure and irritation of the neurosensory receptors that can create pain. Kinesiotaping application on the skin can "lift" the skin layer, thereby reducing the stress on nociceptive receptors on the skin. Another theory for KT in decreasing pain was by improving lymphatic and blood circulation without restricting the ROM of the affected part. The tape microscopically lifts the skin, increasing lymphatic drainage and thus reducing inflammation in the affected areas., ${ }^{7}$ Range of motion is defined as the movable range of a joint's potential movement. Good range motion prevents unnecessary energy consumption, enhances accuracy and muscle activity during exercise, and improves coordination. ${ }^{15,16}$ This study showed a statistically significant improvement in moving the shoulder flexion and abduction after KT application. Some participants even showed an increase of shoulder movement of more than $20^{\circ}$ at the end of the evaluation, 
that can be assumed as clinical significance based on the study done by Thelen et al., which stated an increase of ROM of more than $20^{\circ}$ was considered to have clinical relevance. ${ }^{17}$ Two mechanisms was proposed to explain how KT can improve the range of motion of the active joint, one of them is by reducing the density between layers of skin in the area applied with KT, which will make the skin layer change (convolution), thereby increasing the range of motion of the joints and reducing pain. The second theory is that attachment of KT increases sensory feedback, which reduces fear of movement and reduces pain so that patients can move the joints and allow an increased active range of motion. ${ }^{18}$

As the pain and range of motion increased, this study also shows that subjects have increased upper limb functional ability by the SPADI score at the end of the study. The SPADI consists of 13 items that were developed to evaluate shoulder pain and disability. The SPADI has reliability coefficients of ICC $\geq$ 0.89 in a variety of patient populations. Its internal consistency is high, with Cronbach's typically exceeding. ${ }^{18,19}$

Results of this study support that KT will encourage pain relief, but still, it does not represent a reason for it to become the primary treatment of choice. This study has several limitations, it includes all etiology of shoulder pain in inclusion criteria and was done in a limited population (leisure athlete). Another limitation is the limited duration of the followup, so the result cannot determine whether KT is the treatment of choice or not for long-term shoulder pain. However, same with another study before, a combination of low cost, limited risk of complications, and immediate reduction in pain, supports the use of $\mathrm{KT}$ as an adjunct or complementary technique to reduce shoulder pain.

\section{CONCLUSIONS}

Kinesiotaping has a medium-term effect on reducing shoulder pain, increasing the ability of flexion and abduction range of motion of shoulder joint, and improving functional ability of upper limb in shoulder pain subjects.

\section{REFERENCES}

1. Cadogan A, Laslett M, Hing WA, McNair PJ, Coates MH. A prospective study of shoulder pain in primary care: Prevalence of imaged pathology and response to guided diagnostic blocks. BMC Musculoskelet Disord 2011; 12: 119.

2. Simsek HH. Does Kinesio taping in addition to exercise therapy improve the outcomes in subacromial impingement syndrome? A randomized, double-blind,controlled clinical trial. Acta Orthop Traumatol Turc 2013; 47(2): 104-10.

3. Linaker $\mathrm{CH}$, Walker-Bone K. Shoulder disorders and occupation. Best Pract Res Clin Rheumatol 2015; 29(3): 405-23.

4. Bhawna, Multani N, Kundu ZS. Prevalence of shoulder pain among adults in northern india. AJHMR 2016; 2(2): 18-22.

5. Fellow-Arthroscopy \& Sports Medicine, Ortho, One-Orthopaedic Specialty Centre, Coimbatore, Tamilnadu, India., Srinivasan DK, Sahanand Santosh K, Narayana 
Dev A, Rajan David V, et al. Knee and shoulder injury risk assessment in school level female basketball players: a cross sectional study. Int J Physiother Res 2015; 3(1): 905-10.

6. Wilk KE, Macrina LC, Fleisig GS, Porterfield R, Simpson CD, Harker P, et al. Correlation of glenohumeral internal rotation deficit and total rotational motion to shoulder injuries in professional baseball pitchers. Am J Sports Med 2011; 39(2): 329-35.

7. Mostafavifar M, Wertz J, Borchers J. A systematic review of the effectiveness of kinesio taping for musculoskeletal injury. Phys Sportsmed 2012; 40(4): 33-40.

8. Artioli DP, Bertolini GRF. Kinesio taping: application and results on pain: systematic review. Fisioter E Pesqui 2014; 21(1): 94-9.

9. Shakeri H, Keshavarz R, Arab AM, Ebrahimi I. Clinical effectiveness of kinesiological taping on pain and painfree shoulder range of motion in patients with shoulder impingement syndrome: a randomized, double blinded, placebocontrolled trial. Int $\mathrm{J}$ Sports Phys Ther 2013; 8(6): 800-10.

10. González-Iglesias J, Fernández-de-LasPeñas C, Cleland JA, Huijbregts P, Del Rosario Gutiérrez-Vega M. Short-term effects of cervical kinesio taping on pain and cervical range of motion in patients with acute whiplash injury: a randomized clinical trial. J Orthop Sports Phys Ther 2009; 39(7): 515-21.

11. Ujino A, Eberman LE, Kahanov L, Renner C, Demchak T. The Effects of Kinesio Tape and Stretching on Shoulder ROM. Int J Athl Ther Train [Internet]. 2013 Mar 1 [cited 2019 Apr 20]; Available from: https://journals.humankinetics.com/doi/ abs/10.1123/ijatt.18.2.24

12. Paoloni M, Bernetti A, Fratocchi G, Mangone M, Parrinello L, Cooper MDP, et al. Kinesio Taping applied to lumbar muscles influences clinical and electromyographic characteristics in chronic low back pain patients. Eur J Phys Rehabil Med 2011; 47(2): 9.

13. Kaya E, Zinnuroglu M, Tugcu I. Kinesio taping compared to physical therapy modalities for the treatment of shoulder impingement syndrome. Clin Rheumatol 2011; 30(2): 201-7.

14. Gosling AP. Mecanismos de ação e efeitos da fisioterapia no tratamento da dor. Rev Dor 2012; 13(1): 65-70.

15. Cho H, Kim E-H, Kim J, Yoon YW. Kinesio taping improves pain, range of motion, and proprioception in older patients with knee osteoarthritis: a randomized controlled trial. Am J Phys Med Rehabil 2015; 94(3): 192-200.

16. Eom SY, Lee WJ, Lee JI, Lee EH, Lee HY, Chung EJ. The effect of ankle Kinesio taping on range of motion and agility during exercise in university students. Phys Ther Rehabil Sci 2014; 3(1): 63-8.

17. Thelen MD, Dauber JA, Stoneman PD. The Clinical Efficacy of Kinesio Tape for Shoulder Pain: A Randomized, DoubleBlinded, Clinical Trial. J Orthop Sports Phys Ther 2008; 38(7): 389-95.

18. Breckenridge JD, McAuley JH. Shoulder Pain and Disability Index (SPADI). J Physiother 2011; 57(3): 197.

19. Roy J-S, MacDermid JC, Woodhouse LJ. Measuring shoulder function: A systematic review of four questionnaires. Arthritis Care Res 2009; 61(5): 623-32. 